\title{
Health Belief Model for the Analysis of Factors Affecting Hypertension Preventive Behavior among Adolescents in Surakarta
}

\author{
Rumeyda Chitra Puspita'), Didik Tamtomo²), Dono Indarto 3) \\ 1) Masters Program in Public Health, Sebelas Maret University \\ 2) Department of Anatomy, Faculty of Medicine, Sebelas Maret University \\ 3) Department of Physiology, Faculty of Medicine, Sebelas Maret University
}

\begin{abstract}
Background: Hypertension is an important public health issue in developed and developing countries. The incidence of hypertension continues to rise to a serious level. Raising awareness of the seriousness of hypertension among peer groups may be an important factor for preventive health behavior. This study aimed to examine the used of health belief model for the analysis of factors affecting hypertension preventive behavior among adolescents.

Subjects and Method: This study was an observational analytic study with cross sectional design. It was conducted at 5 Vocational High Schools (SMK) in Surakarta from April to May, 2017. A sample of 200 class X and XI SMK students aged 15-17 years was selected for this study by stratified random sampling. The dependent variable was hypertension preventive behavior. The independent variables were perceived susceptibility, perceived seriousness, perceived benefit, perceived barriers, cues to action, and self efficacy, with perceived threat as a mediating variable. The data were collected by a set of pre-tested questionnaire. Path analysis was employed for data analysis using SPSS AMOS 22.

Results: Perceived threat $(b=0.24, S E=0.07, p=0.002)$, perceived benefit $(b=0.24, S E=0.10$, $\mathrm{p}=0.021)$, self efficacy $(\mathrm{b}=0.40, \mathrm{SE}=0.23, \mathrm{p}=0.084)$, and cues to action $(\mathrm{b}=0.45, \mathrm{SE}=0.15$, $\mathrm{p}=0.003$ ) showed direct positive effects on hypertension preventive behavior. Perceived barrier $(b=-0.26, S E=0.10, p=0.015)$ showed direct negative effect on hypertension preventive behavior. Perceived susceptibility $(b=0.27, S E=0.09, p=0.005)$, perceived seriousness $(b=0.29, S E=0.09$, $\mathrm{p}<0.001)$, and cues to action $(\mathrm{b}=0.34, \mathrm{SE}=0.13, \mathrm{p}=0.008)$ showed indirect positive effects on hypertension preventive behavior.

Conclusion: Hypertension preventive behavior is positively and directly affected by perceived threat, perceived benefit, self, and cues to action. The preventive behavior is negatively and directly affected by perceived barrier. Perceived susceptibility, perceived seriousness, and cues to action indirectly and positively affect on hypertension preventive behavior.
\end{abstract}

Keywords: health belief model, hypertension, preventive behavior, adolescents

\section{Correspondence:}

Rumeyda Chitra Puspita. Masters Program in Public Health, Sebelas Maret University, Jl. Ir. Sutami 36 A, Surakarta 57126, Central Java. Email: rumeydacp@gmail.com.

Mobile: +6287736044472.

\section{BACKGROUND}

Epidemiology transition occurs in Indonesia currently results in the change in pattern of infectious diseases into non communicable diseases (NCDs). Epidemiology transition is caused by the occurrence of transformation on social economy, environment, and unhealthy life style. Non-com- municable diseases are the main factor of morbidity and mortality issues including among others is hypertension. (Rahajeng and Tuminah, 2009). Hypertension is the main health problem both in developed and developing countries. Hypertension epidemic that keeps on increasing turns to serious warning to pay attention more on 
the diseases what so called as silent killer (Kamran et al., 2014).

The high prevalence of hypertension is related to cardiovascular diseases (CVD), cerebrovascular (stroke), chronic kidney diseases (CKD), retinopathy, and early death (Erem et al., 2009; Vimala et al., 2009; El-hay and Mezayen, 2015). Global hypertension prevalence was $22.25 \%$ in 2014. A total of 9.4 million lives are estimated die every year, with $45 \%$ die for heart diseases and $51 \%$ die for stroke. South-East Asia Regional (SEAR) stand among the top three in global hypertension cases with percentage 24.75\% (WHO, 2015). Hypertension prevalence in Indonesia based on Basic Health Research (Riskesdas) 2013 was $26.5 \%$, whereas for adolescents aged 15-17 years, hypertension prevalence was 5.3\% (Riskesdas, 2013).

Setiyaningsih et al. (2016) stated that hypertension prevalence mostly happens to elderly, however hypertension prevalence on productive age is likely to increase from year to year.

The high blood pressure is caused by biological factor that cannot be modified and behavior factor that can trigger hypertension (Fitriani, 2012; Sandberg and Ji, 2012; Herwati and Sartika, 2014; El-Hay and Mezayen, 2015; Purwono, 2015; Situmorang, 2015; British Columbia Ministry of Health, 2016). Unmodifiable biological factors among others are age, sex categories, family disease history (Manimunda et al., 2011). Behavior factors include unhealthy life style on adolescents such as smoking and drinking alcohol that may generate 1 time higher possibility to endure hypertension (Holmes et al., 2013).

According to Loh et al. (2013) individual with obesity (Body Mass Index (BMI) $\geq 27.0 \mathrm{~kg} / \mathrm{m}^{2}$ ) possess 2.3 times bigger possibility to endure hypertension compare to normal BMI. It is linked with the frequent consumption of fatty food and lacked of physical activity. Individual who often consumes fatty food is 2.1 times at risk for hypertension (Sugiharto, 2007) and individual with moderate/ medium physical activity is 1.4 times likely to endure hypertension (Loh et al., 2013). Individual with excessive salt intake or often consumes salty food is 4.3 times at risk for hypertension compares to individual without habit of consuming salty food (Sugiharto, 2007).

Menurut $\mathrm{Hu}$ et al. (2015) stress level contribute about $9.1 \%$ for the risk of hypertension. Individual with high level of stress will influence her sleeping quality, whether it is sleeping disorder, short sleep (stay up late) or poor sleeping quality. It allows 1.8 times bigger chance to endure hypertension than individual with no sleeping disorder, short sleep, and poor sleeping quality (Bansil et al., 2011).

In addition to identifying risk factors of hypertension, it is also important to analyze health behavior factor, since adolescence is a transition time from childhood to adulthood in which they endure emotional, intellectual, feeling, and responsibility change (Istiany and Rusilanti, 2013). Health behavior related to hypertension can be studied with health believe model (HBM).

HBM is a behavioral change theory on individual level. The behavior change is divided into 3 (three) parts, the first is individual perception that consists of perceived susceptibility/ vulnerability, perceived severity/ seriousness, perceived threat, perceived benefit, perceived barrier, cues to action and self efficacy, the second is modifying factors and the third is likelihood of action (Burke, 2013; Sulaeman, 2016).

Public awareness raising especially among adolescents is the main key in primarily preventing hypertension. Basically, preventive effort is conducted as early as 
possible before the emergence of the symptoms of the disease by managing, reducing, and controlling the risk factors of hypertension to reduce morbidity and mortality rate of hypertension (WHO, 2013; Rahimi et al., 2015; Sulaeman, 2016).

\section{SUBJECTS AND METHOD \\ 1. Design of the Study \\ The method used in the study was analytic observational, with cross sectional design approach. The implementation times was April-May 2017 in 5 Vocational High Schools in each sub-district of Surakarta}

\section{Population and Sampling}

The population of the study was adolescents/ student of Vocational High School in Surakarta. The subjects of the study were adolescents of Vocational High School who were in grade X and XI (aged 15-17 years), resided in Surakarta municipality as well as were selected as the subject in accordance with inclusion criteria. Inclusion criteria of the study were adolescents who were willing to be study subjects, adolescents/ students of grade $\mathrm{X}$ and $\mathrm{XI}$ aged $\geq 15$ years, adolescents resided in the area of Surakarta municipality, and did not suffer from heart, liver, and kidney diseases.

Subject selection of the study was determined through 2 stages. The first stage was determining location by means of multi stage sampling technique, which was started from determining city, sub-district, Vocational High School and study subjects. The second stage was selecting Vocational High School and study subjects which were conducted by using simple random sampling technique by selecting 200 study subjects.

\section{Variables of the Study}

Independent variables of the study were perceived susceptibility, perceived severity, perceived benefits, perceived barrier, cues to action, and self efficacy. Dependent vari- able was hypertension preventive behavior. Intervening variable of the study was perceived threat.

\section{Operational Definition}

Operational definition of perceived susceptibility was individual subjective belief to feel susceptible/ had the possibility to endure hypertension. Perceived severity was individual belief in considering hoe severe hypertension disease was. Perceived benefit was the belief on advantages/ benefits that would be obtained if conducting preventive behavior, whereas perceived barrier was subjective belief that gave negative impression in conducting preventive behavior. Cues to action factor were incident that influence individual to change the behavior/ take action out of a health threat. Self efficacy was judgment on own ability to conduct hypertension preventive behavior. Perceived threat was motivation to conduct preventive behavior caused by perceived susceptibility and disease severity.

Operational definition of dependent variable preventive behavior was adolescents' behavior to primarily prevent the hypertension incident that consisted of salt and fat diet management, physical activity, smoking habit, and stress management.

\section{Instruments of the Study}

The study employed questionnaires as the data collection technique which was in accordance with health belief model. Validity and reliability test had been conducted to 20 study subjects, and it obtained the measurement result of variables perceived susceptibility, severity, threat, benefit, barrier, cues to action, self efficacy, and hypertension preventive behavior with the item-total correlation value was $>0.20$ and alpha Cronbach $\geq 0.60$, therefore all question items were reliable. The result of questionnaires reliability was presented in Table 1. 
Journal of Health Promotion and Behavior (2017), 2(2): 183-196

https://doi.org/thejhpb.2016.02.02.08

\section{Data Analysis}

The study used univariate analysis to present data characteristics of study subjects and descriptive of variables of the study. Bivariate analysis was used to analyze independent variables toward dependent variable. Path analysis was used for analyzing the influence of independent variables toward dependent variable through intervening variable and recognizing direct and indirect influence of independent variables toward dependent variable. The magnitude of independent variables' influence toward dependent variable could be observed from the value of path coefficient. The steps in conducting path analysis were model specification, model identification, model fit, parameter estimation, and model respesification.

Table 4. Result of reliability test

\begin{tabular}{lcc}
\hline \multicolumn{1}{c}{ Variables } & Item Total Correlation (r) & Alpha Cronbach \\
\hline Perceived Susceptibility & $\geq 0.29$ & 0.72 \\
Perceived Severity & $\geq 0.22$ & 0.74 \\
Perceived Threat & $\geq 0.34$ & 0.75 \\
Perceived Benefit & $\geq 0.23$ & 0.82 \\
Perceived Barrier & $\geq 0.42$ & 0.82 \\
Cues to Action & $\geq 0.34$ & 0.85 \\
Self Efficacy & $\geq 0.25$ & 0.83 \\
Preventive Behavior & & \\
Physical Activity & $\geq 0.20$ & 0.84 \\
Stress Level & $\geq 0.24$ & 0.80 \\
Smoking Behavior & $\geq 0.32$ & 0.77 \\
Salt and Fat Diet & $\geq 0.24$ & 0.76 \\
\hline
\end{tabular}

\section{RESULTS}

$\overline{\text { Results of the study explained about univa- }}$ riate analysis, bivariate analysis, and path analysis.

\section{Univariate Analysis}

Univariate analysis consisted of characterristics of study subjects and description of study variables, as it was presented in Table 2 and 3.

Table 2 showed that proportion of female study subjects were 113 people (56.5\%) and male subjects were 87 people (43.5\%). The age of majority study subjects were 16 years $(53.5 \%), 17$ years $(26.5 \%)$ and 15 years (20.0\%). Study subjects' domiciles were almost evenly distributed, however most adolescents resided in Banjarsari Subdistrict (21.5\%) compared to other Sub-districts.

Study subjects with normal nutriational status BMI/A were $89.5 \%$, nutritional status fat were $6.0 \%$ nutritional status thin were $4.5 \%$. Adolescents with normotension were 111 people (55.5\%), with pre-hypertension were $42.5 \%$ and with hypertension were $2.0 \%$. Out of 200 study subjects, there were a total of $105(52.5 \%)$ who did not have family disease history. Study subjects with family history of hypertension were $22 \%$, diabetes $16 \%$, stroke $6 \%$, heart diseases $3 \%$, and obesity $0.5 \%$.

\section{Bivariate Analysis}

Bivariate analysis was used to see the influence (independent variables) toward hypertension preventive behavior variable (dependent variable).

Table 4 showed that perceived susceptibility $(\mathrm{r}=0.14, \mathrm{p}=0.046)$, perceived severity $(\mathrm{r}=0.28, \mathrm{p}<0.001)$, perceived threat $(\mathrm{r}=0.31, \mathrm{p}<0.001)$, perceived benefit $(\mathrm{r}=$ $0.28, \mathrm{p}<0.001)$, cues to action $(\mathrm{r}=0.28, \mathrm{p}<$ $0.001)$, and self efficacy $(\mathrm{r}=0.25, \mathrm{p}<0.001)$ gave positive influence and statistically significant toward hypertension preventive 
behavior. Perceived barrier ( $\mathrm{r}=-0.25, \mathrm{p}$ significant toward behavior. $<0.001)$ give negative effect and statistically

Table 2. Characteristics of the study subjects

\begin{tabular}{|c|c|c|c|}
\hline Characteristics & & Frequency & $\%$ \\
\hline Sex Categories & $\begin{array}{l}\text { - Male } \\
\text { - Female }\end{array}$ & $\begin{array}{c}87 \\
113\end{array}$ & $\begin{array}{l}43.5 \\
56.5\end{array}$ \\
\hline \multirow[t]{3}{*}{ Age (years) } & -15 & 40 & 20.0 \\
\hline & -16 & 107 & $53 \cdot 5$ \\
\hline & -17 & 53 & 26.5 \\
\hline \multirow[t]{5}{*}{ Residence } & $\begin{array}{l}\text { - Laweyan Sub- } \\
\text { district }\end{array}$ & 39 & 19.5 \\
\hline & $\begin{array}{l}\text { - Serengan Sub- } \\
\text { district }\end{array}$ & 40 & 20.0 \\
\hline & $\begin{array}{l}\text { - Pasar Kliwon } \\
\text { Sub-district }\end{array}$ & 40 & 20.0 \\
\hline & $\begin{array}{l}\text { - Jebres Sub- } \\
\text { district }\end{array}$ & 38 & 19.0 \\
\hline & $\begin{array}{l}\text { - Banjarsari Sub- } \\
\text { district }\end{array}$ & 43 & 21.5 \\
\hline \multirow[t]{3}{*}{ BMI/A } & - Thin & 9 & 4.5 \\
\hline & - Normal & 179 & 89.5 \\
\hline & - Fat & 12 & 6.0 \\
\hline \multirow[t]{3}{*}{ Hypertension status } & - Normotension & 111 & $55 \cdot 5$ \\
\hline & $\begin{array}{l}\text { - Pre- } \\
\text { hypertension }\end{array}$ & 85 & 42.5 \\
\hline & - Hypertension & 4 & 2.0 \\
\hline \multirow[t]{6}{*}{ Family Disease History } & - None & 105 & 52.5 \\
\hline & - Hypertension & 44 & 22.0 \\
\hline & - Diabetes & 32 & 16.0 \\
\hline & - Heart diseases & 6 & 3.0 \\
\hline & - Stroke & 12 & 6.0 \\
\hline & - Obesity & 1 & 0.5 \\
\hline
\end{tabular}

Table 3. Description of variables of the study

\begin{tabular}{lccccc}
\hline \multicolumn{1}{c}{ Variables } & n & Min. & Max. & Mean & SD \\
\hline Perceived Susceptibility & 200 & 14 & 29 & 21.60 & 2.79 \\
Perceived Severity & 200 & 18 & 35 & 25.04 & 3.05 \\
Perceived Threat & 200 & 14 & 37 & 27.67 & 3.98 \\
Perceived Benefit & 200 & 22 & 37 & 30.29 & 2.98 \\
Perceived Barrier & 200 & 8 & 28 & 17.92 & 2.81 \\
Cues to Action & 200 & 0 & 7 & 4.32 & 2.02 \\
Self Efficacy & 200 & 0 & 7 & 5.59 & 1.36 \\
Preventive Behavior & 200 & 10 & 35 & 23.53 & 4.73 \\
\hline
\end{tabular}


Journal of Health Promotion and Behavior (2017), 2(2): 183-196

https://doi.org/thejhpb.2016.02.02.08

Table 4. Result of bivariate analysis on the influence of perceived susceptibility, perceived severity, perceived threat, perceived benefit, perceived barrier, cues to action, and self efficacy toward hypertension preventive behavior

\begin{tabular}{lcc}
\hline Independent variables & $\mathbf{r}$ & p \\
\hline Perceived Susceptibility & 0.14 & 0.046 \\
Perceived Severity & 0.28 & $<0.001$ \\
Perceived Threat & 0.31 & $<0.001$ \\
Perceived Benefit & 0.28 & $<0.001$ \\
Perceived Barrier & 0.25 & $<0.001$ \\
Cues to Action & 0.28 & $<0.001$ \\
Self Efficacy & 0.25 & $<0.001$ \\
\hline
\end{tabular}

\section{Path Analysis}

Path analysis was used to analyze perceived susceptibility, perceived severity, perceived threat, perceived benefit, perceived barrier, cues to action, and self efficacy toward hypertension preventive behavior among adolescents, as it was presented in Picture 1.

Result of degree of freedom (df) was 5 which meant over identified or path analy- sis could be conducted. Image 1 showed structural model after conducting estimation. The model had fulfilled model fit of path analysis with CMIN was as much as 10.17, $\mathrm{p}=0.070>0.050 ; \quad \mathrm{NFI}=0.94 \geq 0.90$; $\mathrm{CFI}=0.96 \geq 0.90 ; \mathrm{GFI}=0.98 \geq 0.90 ; \mathrm{RMSEA}=$ $0.07 \leq 0.08$.

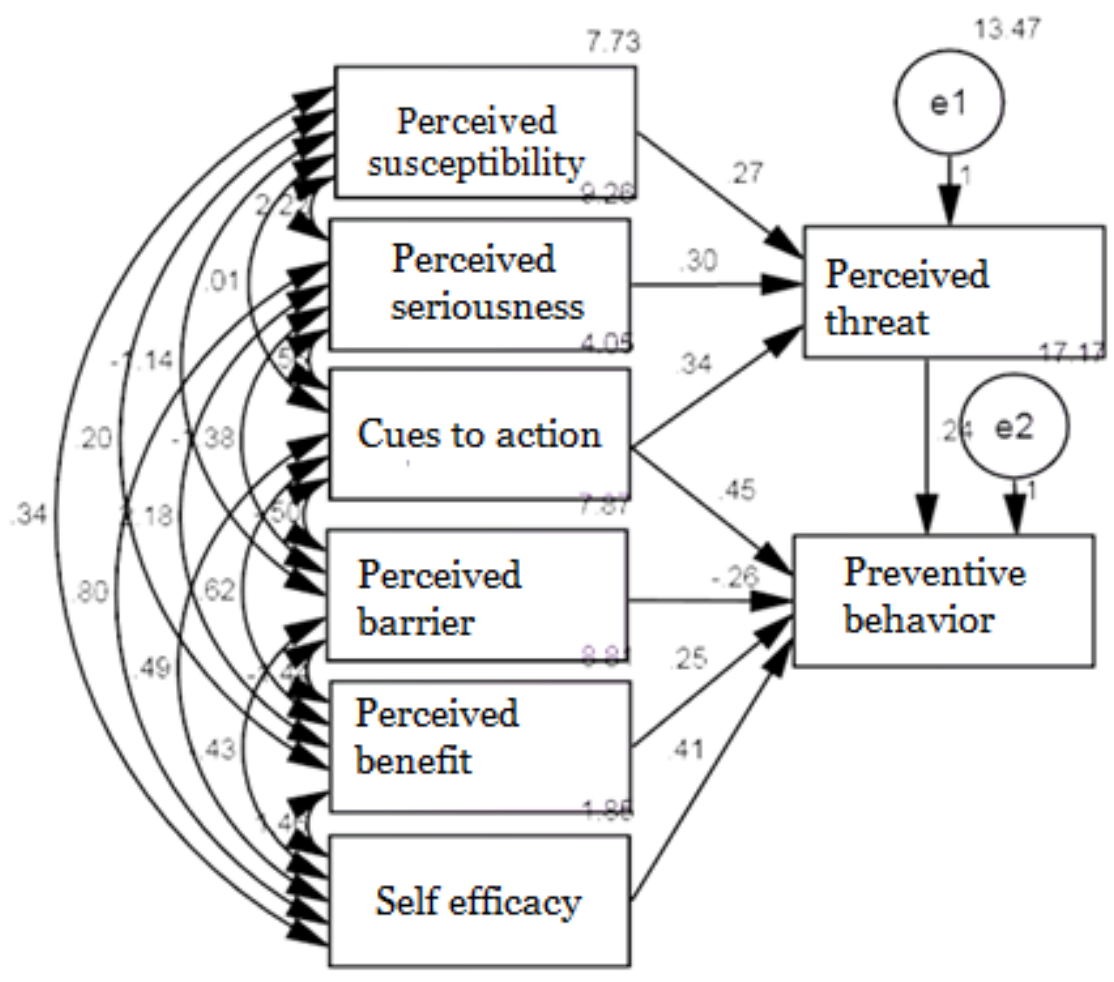

Picture 1. Structural Model of path analysis with estimation 
Table 5. Result of path analysis on health belief model toward hypertension preventive behavior among adolescents in Surakarta

\begin{tabular}{|c|c|c|c|c|c|c|c|}
\hline \multicolumn{3}{|c|}{ Dependent Variables } & Independent Variables & $\mathbf{b}^{*}$ & SE & $\mathbf{p}$ & $\boldsymbol{\beta}^{* *}$ \\
\hline \multicolumn{8}{|c|}{ Direct Influence } \\
\hline \multicolumn{2}{|c|}{ Preventive Behavior } & $\leftarrow$ & Perceived Threat & 0.24 & 0.07 & 0.002 & 0.20 \\
\hline \multicolumn{2}{|c|}{ Preventive Behavior } & $\leftarrow$ & Perceived Benefit & 0.24 & 0.10 & 0.021 & 0.15 \\
\hline \multicolumn{2}{|c|}{ Preventive Behavior } & $\leftarrow$ & Perceived Barrier & -0.26 & 0.10 & 0.015 & -0.15 \\
\hline \multicolumn{2}{|c|}{ Preventive Behavior } & $\leftarrow$ & Cues to Action & 0.45 & 0.15 & 0.003 & 0.19 \\
\hline \multicolumn{2}{|c|}{ Preventive Behavior } & $\leftarrow$ & Self Efficacy & 0.40 & 0.23 & 0.084 & 0.11 \\
\hline \multicolumn{8}{|c|}{ Indirect Influence } \\
\hline \multicolumn{2}{|c|}{ Perceived Threat } & $\leftarrow$ & Perceived Susceptibility & 0.27 & 0.09 & 0.005 & 0.18 \\
\hline \multicolumn{2}{|c|}{ Perceived Threat } & $\leftarrow$ & Perceived Severity & 0.29 & 0.08 & $<0.001$ & 0.22 \\
\hline \multicolumn{2}{|c|}{ Perceived Threat } & $\leftarrow$ & Cues to Action & 0.34 & 0.13 & 0.008 & 0.19 \\
\hline \multicolumn{8}{|c|}{ Model Fit } \\
\hline $\mathrm{p}$ & $=0.070$ & & $(>0.050)$ & & & & \\
\hline CMIN & $=10.17$ & & & & & & \\
\hline GFI & $=0.98$ & & $(\geq 0.90)$ & & & & \\
\hline NFI & $=0.94$ & & $(\geq 0.90)$ & & & & \\
\hline CFI & $=0.96$ & & $(\geq 0.90)$ & & & & \\
\hline RMSEA & $=0.07$ & & $(\leq 0.08)$ & & & & \\
\hline
\end{tabular}

Table 5 showed the result of multivariate analysis with path analysis model. Preventive behavior was influenced by perceived threat, perceived benefit, perceived barrier, cues to action, and self efficacy.

Every one unit increase on perceived threat, would increase hypertension preventive behavior among adolescents by 0.24 unit $(b=0.24, \mathrm{SE}=0.07, \mathrm{p}=0.002)$. Every one unit increase on perceived benefit, would increase hypertension preventive behavior among adolescents by 0.24 unit $(b=0.24, S E=0.10, p=0.021$ ).

Every one unit increase on perceived barrier, would lower down hypertension preventive behavior among adolescents by 0.26 unit ( $b=-0.26, \mathrm{SE}=0.10, \mathrm{p}=0.015)$. Every one unit increase on cues to action, would increase hypertension preventive behavior among adolescents by 0.45 unit $(b=$ $0.45, \mathrm{SE}=0.15, \mathrm{p}=0.003)$. Every one unit increase on self efficacy, would increase hypertension preventive behavior among adolescents by 0.40 unit $(b=0.40, \mathrm{SE}=0.23$, $\mathrm{p}=0.084$ ).
Perceived susceptibility, perceived severity, and cues to action indirectly influence preventive behavior through perceived threat.

Every one unit increase on perceived susceptibility, would increase the score of perceived threath of hypertension among adolescents by 0.27 unit $(b=0.27, \mathrm{SE}=0.09$, $\mathrm{p}=0.005)$. Every one unit increase on perceived severity, would increase the score of perceived threath of hypertension among adolescents by 0.29 unit $(b=0.29, \mathrm{SE}=0.09$, $\mathrm{p}<0.001)$. Every one unit increase on perceived susceptibility, would increase the score of perceived threath of hypertension among adolescents by 0.34 unit $(b=0.34$, $\mathrm{SE}=0.13, \mathrm{p}=0.008$ ).

\section{DISCUSSION}

1. The influence of perceived susceptibility toward hypertension preventive behavior through perceived threat among adolescents in Surakarta.

The result of the study showed that there was an influence of perceived susceptibility 
Journal of Health Promotion and Behavior (2017), 2(2): 183-196

https://doi.org/thejhpb.2016.02.02.08

toward hypertension preventive behavior through perceived threat.

The study is supported by a study conducted by Yue et al. (2017) that hypertension patient's high perceived susceptibility influences the compliance to antihypertension medication. In line with the study, Safitri (2014) in her study, stated that $58.9 \%$ respondents had positive perception toward susceptibility on enduring the risk of hypertension diseases.

Perceived susceptibility is one of strong perceptions for someone to adopt health behavior. Individual with low susceptibility may deny that he/ she is at risk for certain disease, allowing the individual to perform unhealthy behavior. Meanwhile, individual with high perceived susceptibility will get influence by health problems and is more likely to perform health behavior that is reducing the risk of disease development (Contento, 2016; Onoruoiza et al., 2015)

A study by Setiyaningsih et al. (2016) showed that there is indirect influence between perceived susceptibility and hypertension prevention behavior through perceived threat as the intervening variable ( $b=0.35 ; p<0.001)$.

According to Sutrisni (2016) if one feels at risk for certain disease he/ she will perform safe behavior and act of prevention. Individual who thinks to be susceptible will easily get threatened, the threat encourages the individual to perform act of prevention or healing of disease.

Based on the above explanation it can be concluded that there is a positive influence of perceived susceptibility toward hypertension prevention behavior among adolescents indirectly through perceived threat. Therefore the result is in accordance with the previous study and supports Health Belief Model.

\section{The influence of perceived severity toward hypertension preventive behavior through perceived threat among adolescents in Surakarta.}

The result of the study showed that there was an influence of perceived severity toward hypertension preventive behavior through perceived threat.

The study is supported by a study conducted by Kamran et al. (2014) that hypertension patients have high perceived severity toward compliance to hypertension medication.

Perceived severity is an individual feels severity of a health problem. Individual with perceived severity, is more likely to prevent or reduce the severity based on medical information as well as other knowledge (Contento, 2011; Orji et al., 2012; Orlowski, 2016).

A study by Setiyaningsih et al., (2016) showed that there is an indirect influence of perceived severity toward hypertension prevention behavior through intervening variable namely perceived threat $(b=0.48$; $\mathrm{p}<0.001$ ). Sholihah (2014) stated that 53.1\% study subjects have high perceived severity toward hypertension disease, that it increases health behavior.

The study supports Health Belief Model that explains the occurrence of perceived severity or a belief that hypertension is a serious disease and may threaten one's health in the future, therefore an adolescent will as early as possible perform health behavior that is prevention.

\section{The influence of perceived threat toward hypertension preventive be- havior among adolescents in Sura- karta}

The result of the study showed that there was an influence of perceived threat toward hypertension preventive behavior.

The study is supported by Setiyaningsih et al. (2016) who showed that there is a 
direct influence of perceived threat toward hypertension prevention behavior $(b=0.11$; $\mathrm{p}<0.001$ ) a study by Suhadi (2011) that there is a correlation between perceived threat and elderly compliance to hypertension medication $(\mathrm{p}<0.05)$. The threat is increasing therefore prevention behavior toward disease will occur (Setiyaningsih et al., 2016).

Two concepts of perceived threat namely susceptibility felt and level of severity mutually felt represent perceived threat of getting infected by certain disease. The study refers to the prediction on hypertension disease threat. Perceived threat or perceived risk felt may determine the stages or strategy of risk reduction and to increase urgency and motivation to prevent the threat (Tarkang and Zotor, 2015).

Sholihah (2014) stated in a study that most of the study subjects (53.1\%) stated big threat toward hypertension disease, therefore the confidence to perform prevention behavior is getting high.

Based on the above matter, it can be concluded that there is a positive influence of perceived threat toward hypertension prevention behavior among adolescents, with direct association. Therefore, the result of the study is in accordance with the previous studies and supports Health Belief Model theory.

\section{The influence of perceived benefit toward hypertension preventive be- havior among adolescents in Sura- karta}

The result of the study showed that there was an influence of perceived benefit toward hypertension preventive behavior among adolescents. In accordance with a study by Sholihah (2014) that stated the study subjects have bigger perceived benefit than perceived barrier to perform prevention behavior (65.6\%).
Perceived benefit is the benefit felt in improving health behavior to reduce the risk of diseases (Onoru-oiza et al., 2015). One will consider benefit/ advantages obtained between the cost spent and the level of disease. If one believes that certain action will reduce the susceptibility toward certain disease or lower down its severity, he/ she is more likely to involve in health behavior despite the objective facts on the effectiveness of the action (Glanz et al., 2008; Contento, 2011; Orji et al., 2012; Orlowski, 2016).

A study by Barros et al. (2014) explained that study subjects felt the benefits obtained in performing health behavior by consuming anti-hypertension medicines by $91.7 \%$, despite numerous barriers such as financial difficulties, as well as the unavailability of the medicines in the puskesmas pharmacy, that they should obtain in other pharmacy with higher price.

A study by Setiyaningsih et al., (2016) showed there is a positive influence of perceived benefit toward hypertension prevention $(b=0.12 ; p=0.005)$. Setiyaningsih et al. (2016) added that benefit in performing action directly motivates the behavior and indirectly determine the activity plan to achieve the benefit as the positive result.

Based on the above explanation, it can be concluded that there is a positive influence of perceived benefit toward hypertension preventive behavior among adolescents, which is directly associated. Therefore, the result is in accordance with the previous studies and supports Health Belief Model theory.

\section{The influence of perceived barrier toward hypertension preventive be- havior among adolescents in Sura- karta}

The result of the study showed that there was an influence of perceived barrier toward hypertension preventive behavior. 
Journal of Health Promotion and Behavior (2017), 2(2): 183-196

https://doi.org/thejhpb.2016.02.02.08

The study is supported by a study by Sholihah (2014) that there is an influence of perceived barrier felt to perform preventive behavior. Similar study by Kamran et al., (2014) stated that study subjects felt high perceived barrier (22-/184, 12\%) medium (24/190, 12.6\%) and low barrier (115/297, $38.7 \%)$ toward the compliance of hypertension medication.

Perceived barrier is individual/ adolescent who undergoes barrier in performing health behaviors. Perceived barrier refers to the belief toward various barriers (cost, transportation, danger, inconvenience, and the behavior itself) in performing health behavior. Out of all HBM constructs, perceived barrier is one of the most significant in determining behavior change (Glanz et al., 2008; Contento, 2011; Orji et al., 2012; Orlowski, 2016).

A study by Setiyaningsih et al., (2016) stated there is negative influence of perceived barrier toward hypertension preventive behaviors $(b=-0.10 ; p<0.001)$. A study by Yue et al., (2017) stated that low perceived barrier $(\mathrm{p}<0.001)$ is significant if it is related to compliance to anti-hypertension medication.

Similar to the previous study, the numerous barriers or obstacles undergone by adolescents may influence to perform health behavior, such as lack of motivation to exercise and afraid of getting injured or pain because of exercise, personal shame to have blood pressure check (Rimando, 2015).

Based on the explanation above it can be concluded that there is negative influence of perceived barrier toward hypertension preventive behavior, which is directly associated. Therefore the result is accordance with the previous studies and supports Health Belief Model theory.

\section{The influence of cues to action toward hypertension preventive be- havior among adolescents in Sura- karta}

The result of the study showed that there was an influence of cues to action factor toward hypertension preventive behavior.

A study by Sholihah (2014) stated that there were $59.4 \%$ study subjects who had cues to action to perform health behaviors.

Cues to action can influence behavior (Huang et al., 2016), since cues to action is incidents, experiences, physical symptoms (physical condition of health condition), interpersonal or environment that influence someone to perform behaviors (Tarkang and Zotor, 2015).

The theory is supported by a study by Kasmaei et al. (2015) that stated there is a significant and positive association between self care behavior toward hypertension and cues to action construct $(b=0.19, S E=0.06$, $\mathrm{p}=0.02)$.

According to Jones et al. (2015) cues to action is still the latest construction in larger HBM framework, the study analyzed the influence of external cues toward the action, in form of news or knowledge information in this term was about hypertension, and there was no analysis on internal action that should be conducted (example: the symptoms endured).

Based on the above explanation it can be concluded that there is positive influence between cues to action with hypertension prevention behavior among adolescents that directly associated. The study is in accordance with the previous studies and supports Health Belief Model theory.

7. The influence of cues to action toward hypertension preventive behavior, through perceived threat among adolescents in Surakarta

The result of the study showed that there was an influence of cues to action factor 
toward hypertension preventive behavior through perceived threat.

A study by Setiyaningsih et al. (2016) showed that cues to action $(b=0.33$; $\mathrm{p}<0.001)$ is positively and indirectly associated with hypertension preventive behavior.

The combination of variables perceived threat and behavior may achieve relatively high intensity level to generate behavior on individuals. Hence, cues for determining action is added into the model to show the trigger of health behavior if there is an appropriate belief (Orji et al., 2012)

Cues to action is when one senses intention to take action after believing that one has the ability to do so. The action is considered beneficial by knowing how to face the threat occurs. It needs motivation from other parties to have the intention to comply the behavior, to have concerns on threatening health problems, to be willingly seek for and obtain health treatment and to get involved in positive health activities (Tarkang and Zotor, 2015)

Based on the above explanation it can be concluded that there is a positive influence of cues to action with hypertension prevention behavior among adolescents, indirectly through perceived threat. Therefore the result is in accordance with the previous studies and supports Health Belief Model theory.

\section{The influence of self efficacy to- ward hypertension preventive beha- vior among adolescents in Surakarta}

The result of the study showed that there was an influence of self efficacy toward hypertension preventive behavior.

A study by Sholihah (2014) stated that a total of $71.9 \%$ study subjects who performed health behavior based on self confidence. A similar study by Kamran et al. (2014) a total of 88/262 (33.6\%) study subjects with high self efficacy had far higher level of compliance than study subjects who had moderate and low self efficacy.

Self efficacy refers to belief on individual's capacity to get involved in health behavior. Self efficacy is added in HBM theory in order to explain the involvement of health related behaviors (Orji et al., 2012; Battista and Bushman, 2014; Orlowski, 2016; Sulaeman, 2016).

Glanz et al. (2008) added that self efficacy is a key component of heath behavior change. HBM is then applied more on long term health behavior such as diet, exercise, and smoking modification.

A study by Setiyaningsih et al. (2016) showed that there is a positive influence of self efficacy and hypertension prevention behavior $(b=0.11 ; p<0.001)$.

With a confidence, one believe that by performing certain behavior, in this term is preventive behavior, will hel to avoid or prevent the occurrence of health problems/ diseases. The belief gives self confidence to take action to accomplish the expected result. HBM suggests that the belief on the effectiveness of health behavior in preventing hypertension disease should positively correlate with the consistence of the adolescents themselves (Tarkang and Zotor, 2015).

Based on the above explanation it can be concluded that there is a positive influence of self efficacy toward hypertension prevention behavior among adolescents, which is directly associated. Therefore the result of the study is in accordance with the previous studies and supports Health Belief Model theory.

\section{REFERENCE}

Bansil P, Kuklina EV, Merritt R, Yoon PW (2011). Associations Between Sleep Disorders, Sleep Duration, Quality 
Journal of Health Promotion and Behavior (2017), 2(2): 183-196

https://doi.org/thejhpb.2016.02.02.08

of Sleep, and Hypertension: Results from The National Health and Nutrition Examination Survey, 2005 to 2008. American Society of Hypertension 13(10): 739-743.

Barros AA, Vilani M, Guedes C, De D, Moreira Moura, J, Gomes De Menezes, LC, Xavier GA (2014). Health Behaviors of People With Hypertension: Health Belief Model, Rev. Rene 15(3): 525-32.

Battista R, Bushman B (2014). ACSM's Resources for The Personal Trainer. America College of Sports Medicine.

British Columbia Ministry of Health (2016). Hypertension-Diagnosis and Management, 6 .

Burke (2013). The Health Belief Model. Image From: http://currentnursing.com/nursing_theory/health_belief_ model.html. Diakses 4 Februari 2017.

Contento IR (2011). Nutrition Education: Lingking Research, Theory and Practice 2nd Ed. Jones and Bartlett Publishers, LLC.

El-Hay SAA, Mezayen SEEl (2015). Knowledge and Perceptions Related to Hypertension, Lifestyle Behavior Modifications and Challenges That Facing Hypertensive Patients. IOSR Journal of Nursing and Health Science Version. I, 4(6): 2320-1940.

Erem C, Hacihasanoglu A, Kocak M, Deger, O, Topbas M (2009). Prevalence of Prehypertension and Hypertension and Associated Risk Factors Among Turkish Adults: Trabzon Hypertension Study. Journal of Public Health, 31(1): 47-58.

Fitriani A (2012). Kondisi Sosial Ekonomi Stress pada Wanita Hipertensi Anggota Majelis Taklim. Jurnal Kesehatan Masyarakat Nasional 7(5): 214-218.

Glanz K, Rimer BK, Viswanath K (2008). Health Behavior and Health Edu- cation: Theory, Research, and Practice. San Francisco Jossey-Bass.

Herwati, Sartika W (2014). Terkontrolnya Tekanan Darah Penderita Hipertensi Berdasarkan Pola Diet Kebiasaan Olahraga di Pag Tahun 2011. Jurnal Kesehatan Masyarakat, 8(1): 8-14.

Hu B, Liu X, Yin S, Fan H, Feng F, Yuan J (2015). Effects of Psychological Stress on Hypertension in Middle-Aged Chinese: A Cross-Sectional Study. PLOS ONE, 10(6).

Huang HT, Kuo YM, Wang SR, Wang CF, Tsai CH (2016). Structural Factors Affecting Health Examination Behavioral Intention. International Journal of Environmental Research and Public Health, 13(4).

Istiany A, Rusilanti (2013). Gizi Terapan. Edisi Pertama. Bandung: PT. Remaja Rosdakarya.

Jones CL, Jensen JD, Scherr CL, Brown, NR, Christy K, Weaver J (2015). The Health Belief Model as an Explanatory Framework in Communication Research: Exploring Parallel, Serial, and Moderated Mediation. Health Communication, 30(6): 566-576.

Kamran A, Sadeghieh AS, Biria M, Malepour A, Heydari H (2014). Determinants of Patient's Adherence to Hypertension Medications: Application of Health Belief Model Among Rural Patients. Annals of Medical and Health Sciences Research, 4(6).

Kasmaei P, Yousefi P, Farmanbar R, Omidi S, Hassankiadeh RF (2015). A Study on the Predictive Power of the Health Belief Model Constructs in Self-Care Behaviors of Patients with Hypertension. Health Education and Health Promotion (HEHP) 3.

Loh KW, Rani F, Chan TC, Loh HY, Ng CW, Moy FM (2013). The Association Between Risk Factors and Hypertension 
in Perak, Malaysia. Medical Journal of Malaysia, 68(4): 291-296.

Manimunda SP, Sugunan AP, Benegal V, Balakrishna N, Rao MV, Pesala KS (2011). Association of hypertension with risk factors and hypertension related behaviour among the aboriginal Nicobarese tribe living in Car Nicobar Island, India. Indian Journal of Medical Research, 133(3): 287-293.

Onoruoiza SI, Musa A, Umar BD, Kunle YS (2015). Using Health Beliefs Model as an Intervention to Non Compliance with Hypertension Information among Hypertensive Patient. International Organization of Scientific Research Journal Of Humanities And Social Science, 20(9): 11-16.

Orlowski M (2016). Introduction to Health Behavior: A Guide for Managers, Practitians and Educators. Cengage Learning

Purwono J (2015). Hubungan Sikap Persepsi Manfaat dengan Komitmen Pencegahan Tersier Penyakit Hipertensi pada Masyarakat di Wilayah Kerja Puskesmas Se-Kota Metro. Jurnal Kesehatan Metro Sai Wawai, VIII(2), 37-42.

Rahimi K, Emdin CA, MacMahon S (2015). The Epidemiology of Blood Pressure and Its Worldwide Management. Circulation Research, 116(6), 925-935.

Rimando M (2015). Perceived Barriers to and Facilitators of Hypertension Management among Underserved African American Older Adults. Ethnicity and Disease, 25(3): 329-336.

Riskesdas (2013). Riset Kesehatan Dasar Tahun 2013. Badan Penelitian Pengembangan Kesehatan Kementerian Kesehatan RI.

Safitri L (2014). Gambaran Penerapan Teori Health Belief Model Dalam Kepatuhan Pasien Hipertensi di Poli- klinik Khusus Hipertensi RSUP Dr. M. Djamil Pag. Universitas Andalas.

Sandberg K, Ji H (2012). Sex differences in primary hypertension. Biology of Sex Differnces, 3(7): 1-21.

Setiyaningsih R, Tamtomo D, Suryani N (2013). Health Belief Model: Determinants of Hypertension Prevention Behavior in Adults at Community Health Center, Sukoharjo, Central Java. Journal of Health Promotion and Behavior 1(3): 165-175.

Sholihah M (2014). Analisis Perubahan Perilaku Merokok Pada Pasien Hipertensi di Puskesmas Ciputat Tangerang Selatan. Universitas Islam Negeri Syarif Hidayatullah: Jakarta.

Situmorang PR (2015). Faktor-Faktor yang Berhubungan dengan Kejadian Hipertensi pada Penderita Rawat Inap Di Rumah Sakit Umum Sari Mutiara Medan Tahun 2014. Jurnal Ilmiah Keperawatan, 1(1): 67-72.

Sugiharto A (2007). Faktor-Faktor Risiko Hipertensi Grade II Pada Masyarakat (Studi Kasus Di Kabupaten Karanganyar). Tesis Universitas Diponegoro: Semarang.

Suhadi (2011). Analisis Faktor-Faktor Yang Mempengaruhi Kepatuhan Lansia Dalam Perawatan Hipertensi Di Wilayah Puskesmas Srondol Kota Semarang. Jakarta: Universitas Indonesia. Tesis

Sulaeman ES (2016). Pembelajaran Model Teori Perilaku Kesehatan Konsep Aplikasi Ed.1. Surakarta: Sebelas Maret University Press.

Sutrisni, Demartoto A, Respati SH (2016). Health Belief Model Analisis Jalur tentang Faktor yang Mempengaruhi Kesediaan Tes Human Immunodeficiency Virus pada Ibu Hamil di Kota Kediri. Thesis.

Tarkang EE, Zotor FB (2015). Application of the Health Belief Model (HBM) in 
Journal of Health Promotion and Behavior (2017), 2(2): 183-196

https://doi.org/thejhpb.2016.02.02.08

HIV Prevention: A Literature Review.

Central African Journal of Public Healh 1(1): 1-8.

Vimala A, Ranji SA, Jyosna MT, Chandran V, Mathews SR, Pappachan JM (2009). The Prevalence, Risk Factors and Awareness of Hypertension in an Urban Population of Kerala (South India), Saudi Journal of Kidney Diseases and Transplantation, 20(4): 685-689.

WHO (2013). A Global Brief on Hyper- tension: Silent Killer, Global Public Health Crisis. World Health Day 2013 WHO (2015). World Health Statistics 2015. WHO Library Cataloguing-in-Publication Data.

Yue Z, Li C, Weilin Q, Bin W (2017). Application of the health belief model to improve the understanding of antihypertensive medication adherence among Chinese patients. Patient Education and Counseling, 98(5): 669673. 